\title{
九州山地に扫ける山茶の利用形態
}

一熊本県五木地方の例——

\section{山本正 三}

はしがき 果樹および特用作物の利用形態は，野生の利用に始まり，そ の栽培作物化から，更に品種の改良を経て，逐次集約化の方向に発達した ことが考へられるが，茶についても同㥞な過程，山茶の利用から，その園 茶化，集約化の過程が観察される1). わが国の茶業の起源も山茶の利用に 始まることが推測されるが，山茶の園茶化の過程については詳細は明らか にされていない，それはわが国の茶業が，遠い昔にこの過程を通過してし まい，ほとんどこの過程を直接目に触れる機会を失つてしまつていること によるのであるが，幸い，今日でも九州と四国の山地には山茶利用は存続 しており，しかもそこでは，園茶化の過程が 進行しつつあるので，少くとも，ある程度茶 業進化の初期の段階を推察することが可能で あるように思われる．筆者は山茶利用が最も 盛んな熊本県球磨郡五木地方の例を中心に, それに隣接する五家荘および宮崎県米良地方， 大分県日田郡津江地方, 福岡県八女郡の山地 など（第1図）の例を比較しつつ，山茶の利 用形態とその存立条件，およびその将来につ いて若千の考察を試みた。

山茶利用の一般的性格 わが国における茶 業の起源は 9 世紀以前に中国から仏教徒によ つて，茶の製法と栽培法が伝来されたことに 始まるといわれるが，全国的に発達したのは

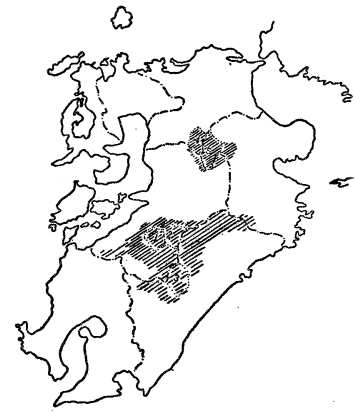

第 1 図 商品生産的山茶 利用地域
1. 五木村
2. 五家荘
3. 米良荘
4. 福岡県八
女郡山地
5. 大分県日

田郡津江地方

1) E. W. Zimmermann (1951): World resources and industries, pp. 375 6. アッサム地方では 1830 年代に野生茶がプランテーションに利用されはじめた. セイロンやインドシナなどでは今日でも土着人による野生茶の園芸化が頻繁に行 われている. C. R. Harler (1956): The culture and marketing of tea. 2 nd edition, p. 16,133 . 


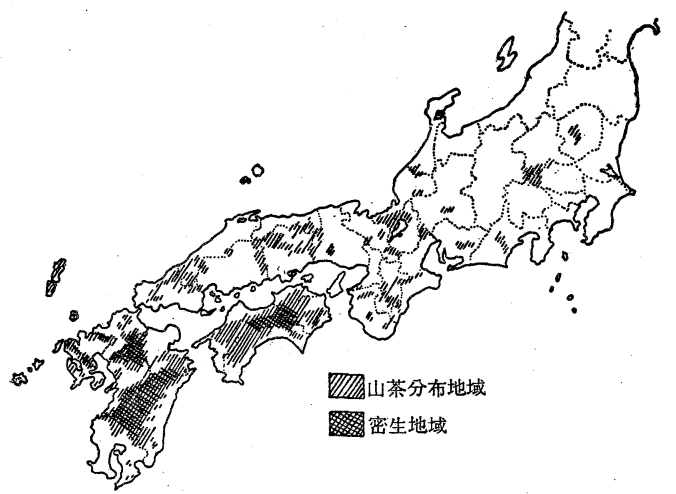

第 2 図 山茶の分布（谷口熊之助「ヤマチャ」調查 抢よび農林省九州農業試験場茶業部資料に よる)

中世以後, 特に近世 中期以降である.わ が国の山野には山茶 が広く生育している （第 2 図）加，それ は古くから利用され ていたらしく2)今日 栽培される茶樹が， 明治以後改良された ごく一部の品種をの ぞけば3，全く山茶 と同一品種であり 4), また現在の山茶の製 茶法が中国にその原型をもつ古い製茶形態を保存していることなどを考へ 合せると，わが国の茶業は中国伝来の製茶法の山茶への適用に始まつたこ とが推測される。山茶利用の茶業は，わが国の茶業の原初形態であつたと 思われる。山茶利用は近世後期，そして明治初期には，まだ全国的にかな り広く分布していたらしく，中国・四国・九州などでは，山茶の商品生産 的利用も行われていたことが知られている5). しかし，明治中期以降，茶

2）一説に静岡県の茶業の起源は，鎌倉初期に安倍郡の人聖一国師が宋より帰り山 地に自生する山茶の管理法，製茶法を人々に伝授したことにはじまるというが， これはわが国の茶業の起源の基本的な型を暗示するもののように思われる．明治 初年以来，わが国の最大の茶業地域となつた静岡県では，幕末から明治初期にか けて行われた茶園の増設に山茶の種子を山野から集めて利用している.

3）昭和 29 年における品種構成在来種 $98 \%$, 改良種 $2 \%$, 農村省特産課の資料による.

4）谷口熊之助（1936）：ヤマチャ調査報告，茶業組合創立 50 周年記念論文集， 87 〜101頁.

5）近世後期には北津軽地方にもみられた.瀬川清子(1956)：食生活の歷史, 116〜7 頁. 高知県物部川上流や熊本県五木，五家荘などでは商品生産的利用がされてい た.青鹿四郎 (1936)：農業経済地理, 396〜7頁.五木村(1953)：村のすがた，57〜8 頁，161 頁. 茶は焼畑の運上物に指定されていた。明治 7 年の物産表および同 10 年の同国普通農産表には，石見，土佐，愛媛など山茶利用のさかんであつた地方 について番茶，下級茶，葉茶，弘法茶，柴茶など山茶によると思われる茶の記載 があり，それが相当な割合を占めている。〔石見 $95 \%$ (明治 7 年), 土佐 $64 \%$ (明治 10)，愛媛 $83 \%$ (明治 7 ) J. また福岡県物産誌（明治 10 年）は筑後山地の茶の大部 
業の発達に圧倒され，また植林の増加，養亘の進展などにつれて山茶利用 は次第に消滅し，今日では九州と四国の山地にのみみられるにすぎなくな つた．商品生産的に利用されているのは，高知県仁淀川流域山茶のほかは， 九州山地のみに限られている6).

九州山地の山茶の分布をみると，そこには地域的，場所的な粗密の差が みられる。一般に高度的には 200 $800 \mathrm{~m}$ に多く，また地質的には古生層特

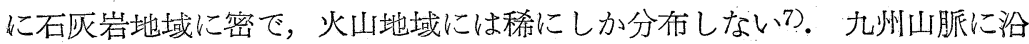

第 1 表 主要山茶利用村の山茶利用状況

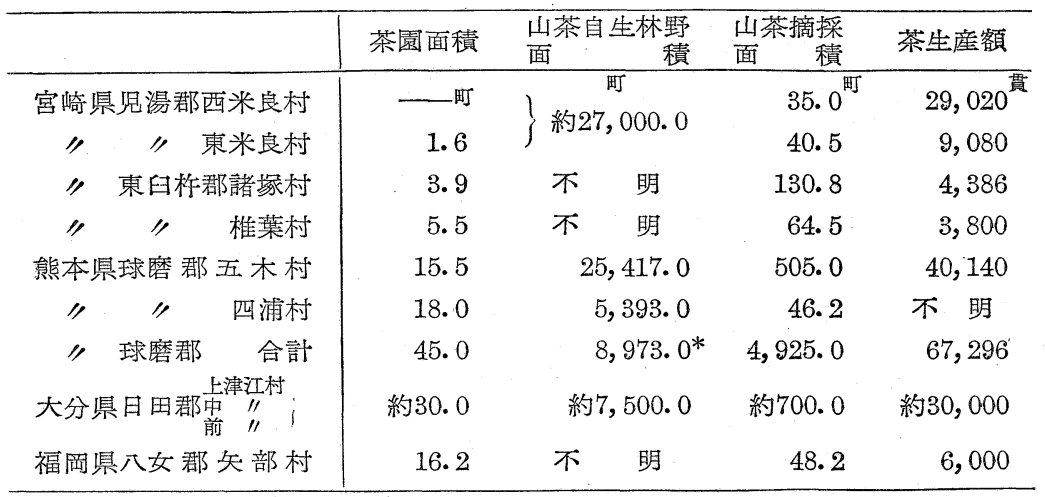

（福岡・熊本県は昭和 27 年，その他は昭和 29 年）

*これは山茶の推定面積. (資料 : 福岡・熊本・宮崎県の各特産課の資料および 山村方正 : 九州地方の山茶について，茶，8，(1955） 12，9，(1956） 1.

う地域に密生地帯がみられる，第 1 表は山茶利用の最も盛んな数村の例で あるが，これらの村々では林野の 4 〜 割以上に山茶が自生してをり，そ の密度は，呠当り $4 \sim 5$ 株以上である. 通常は雑木林などの下生えに混つ

分が天然茶に依存していたことを記載している,[九州近代史叢書第2輯(1956)121， 225 頁】. 明治中期以降消滅した山茶利用が多いことを考兄合せると, 明治初年に は，茶の生産の中に相当量の山茶によるものが含まれていたことは確かであろう。 6）ここでは最近森永紅茶K.K. の委託による紅茶の製造が開始せられた。 九州地 方における山茶摘採面積は約 7500 町（茶園面積より若干少い），九州の全茶生産 の $20 \%$ 以上が山茶による生産である.山茶利用は熊本，宫崎両県が最も盛んて 山茶の生産は全生産の約 $35 \%$ 以上にのぼる. 春田孝夫 (1951) : 九州山村開発と 山茶について，農業経済論集 3 , No. 1 (第 2 表).

7）谷口，前掲 
ているが8，樹木が伐採されると，生育が盛んになり，急速に成長する。 換金作物として山茶が利用されているのは，このような密生地帯である.

山茶利用に共通の特徴は，それが焼畑耕作に附随していることと，その 製茶方法が釜炒方式であることである。この製法は中国渡来のもので，中 央日本では，今日では，滋賀県湖北地方その他に若干存続しているに過ぎ ないが9)，近世中期に宇治方式の蒸製茶法が発明され (1738)，さらに明治 初期に静岡方式に改良されて，全国的に普及する以前には，それはわが国 に広く行われた製茶法であつた. 10)それゆえ，山茶利用の茶業は製茶方式に おいて, 明治以後, 輸出によつて発達した近代茶業以前の形態を保存して

第 2 表 九州における山茶の推定面積(昭和10年)*

\begin{tabular}{|c|c|c|c|c|}
\hline & $\begin{array}{l}\text { 自生山茶 } \\
\text { 摘採面積 }\end{array}$ & $\begin{array}{l}\text { 山茶推定 } \\
\text { 生産 量 }\end{array}$ & 茶園面積 & 全茶生産額 \\
\hline 熊本県 & $5,525^{\text {町 }}$ & 10 万× & $1,492^{\text {町 }}$ & 22.3 万人 \\
\hline 宮 崎 県 & 1,590 & 8 & 1,226 & 22.9 \\
\hline 大 分 県 & 138 & 3.5 & 436 & 6.4 \\
\hline 計 & 7,253 & 21.5 & & \\
\hline
\end{tabular}

（資料：春田孝夫（1951）：九州山村開発と山茶について， 農業経済論集，3，1.)

* 九州管内普通茶園面積は 4,000 町
いるということ が出来る.山茶 利用は，また， 今日，烷畑が減 少の傾向にある ため，炊第に縮 少せしめられつ つあり，多くの 地域に打いて， 消滅か，あるいは園茶への移行を強制せしめられているとみうけられる.

山茶の利用形態〔A．狫畑との関係〕山茶利用の特色を明かにするた めには，その基礎となつている烧畑との関係を考察することが必要である。 焼烟は高度 $200 \mathrm{~m} \sim 1000 \mathrm{~m}$ の間の自然林と植林の伐採跡地のうち，比較 的岩石が少なく，耕土の多い日当りのよい斜面11を選んで行われるが，五 木地方では焼畑の 60〜70\%以上に山茶が自生しており，自生密度も大で

8）針葉林では，植林して長年月を経ると山茶は萎縮し，次第に減少する・杉檜な どの植林では旺盛な山茶の生育をみることはまれである.

9）釜炒製法は山茶の場合をのぞけば，佐賀，熊本，長崎，福岡の一部および大分 など，九州のみにみらるところと云つて過言ではない．消費地も一部北アフッカ に輸出される他，これらの生産諸県に限られている.

10）蒸製が釜炒に代つて普及したのは，全国的には安政 5 年の開港を楔機とする ようであり，静岡県では安政の開港当時鉒炒茶が普及していた，静网県榛原郡茶 業史 (1919) 56, 58, 63〜 78頁

11） $20^{\circ} \sim 30^{\circ}$ の急斜面が多く，時には $45^{\circ}$ 以上の所もある. 
ある。煃畑開始後 $4 \sim 5$ 年目にはほ とんど茶園と見誤るほど，繁茂する ものも稀でない(写真 1)。焼畑は雑 木林の伐採時期（木場切り）と火入 れの時期によつて「秋伐り」と「カ ッ伐り」の 2 つに分けられ，その作 付体系は多種多椂である12)。同じ五 木村内でも部落ごとに違つているが， 比較的広く行われる様式をあげると 第 3 表のごとくである。通常，靚畑

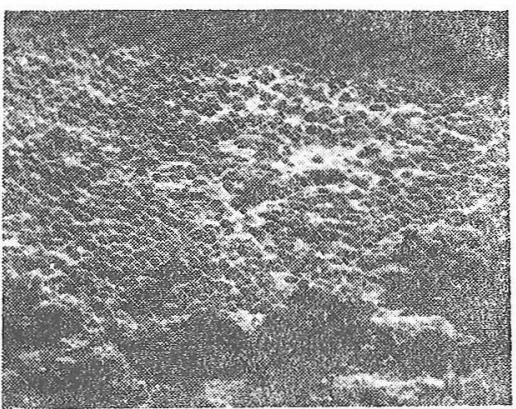

写真 1 焼畑をうめる山茶 (溹畑 5 年目)

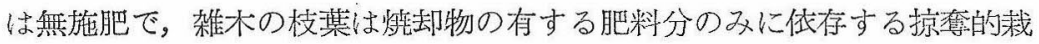
培ち行うため，急速に地力が減退し，4〜5年以上耕作を継続し得なくな り，放裹されるのであるが，山茶の自生の密な烊畑では，山茶が炊第に成 長繁茂するため，3〜 4 年目には作物は茶の間作の姿になり，5年目以後 は，たとへ地力が耕作を可能にしても，作付は因難になる。作付の便宜の

第 3 表 焼畑(木場作)輸作体系(五木村)

\begin{tabular}{|c|c|c|c|c|c|c|c|c|c|c|c|}
\hline \multicolumn{2}{|c|}{ 杢埸の秱数 } & 初年 & 2 年 & 3 年 & 4. 年 & 5 年 & 6 年 & 7 年 & 位置 & 黛摇火 & 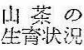 \\
\hline $\begin{array}{l}\text { 夏㦼 } \\
\text { 木場 }\end{array}$ & 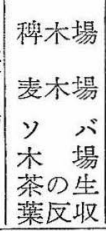 & $\begin{array}{l}\text { 大麦 } \\
\text { 大麦 } \\
\text { ソバ }\end{array}$ & $\begin{array}{r}\text { 禆 } \\
\text { 粟 } \\
\text { 粟 } \\
\text { 貫 } \\
15 \sim 20\end{array}$ & 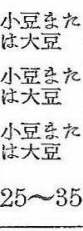 & 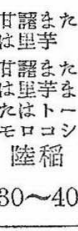 & 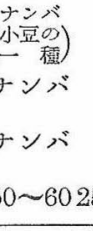 & & & 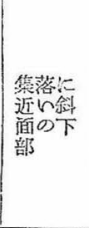 & \multicolumn{2}{|l|}{ 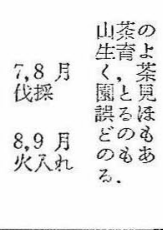 } \\
\hline $\begin{array}{l}\text { 秋䈱 } \\
\text { 太場 }\end{array}$ & $\begin{array}{l}\text { 醀朴場 } \\
\text { 茶の生 } \\
\text { 葉反収 }\end{array}$ & 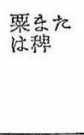 & $\begin{array}{l}\text { 小豆育た } \\
\text { 小豆 } \\
15 \sim 20\end{array}$ & 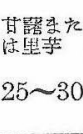 & $\begin{array}{l}\text { トーモロ } \\
\text { コシまを } \\
\text { はナンン゙ } \\
40 \sim 50\end{array}$ & $\sim 30$ & 10 & & $\begin{array}{l}\text { 涂面上 } \\
\text { 部山湏 } \\
\text { 部 }\end{array}$ & 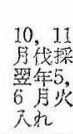 & 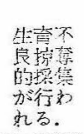 \\
\hline
\end{tabular}

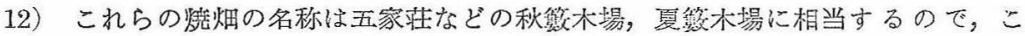
れらの名称を便宜のために使䏹する。秋皦木場は 10〜11 月頃木場切りし，翌年

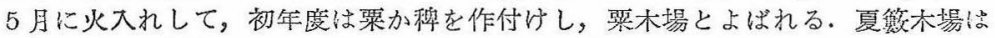
7〜8月に木場切りし，夏の終り，旧盆頃から初秋にかけて火入れし，初年作は ソバで，ソバ木場とよばれる。襄作として大麦の蒔かれる場合もあり，この時に は 2 年 3 作であるが，通常接细は 1 年 1 作であること，他の地域と異ならない。 
ため，繁茂した山茶を刈り取ることもある．山茶は狫畑 3 年目から摘み 始められるのが普通であるが， 2 年目からのも少なくない，摘採は焼畑 6 〜 7 年目まで続き，それ以上には及ばない。五木地方の焼畑は大部分純農 業的焼畑13)である. その休閑期間は 10～ 20 年であるから，山茶の摘採は 12〜13 年ないし 22 23 年の周期でくりかえされる. これを，たとへば大 分県日田郡津江地方のように林業附随的燒畑の卓越する地方で, $30 \sim 40$ 年 以上の周期で山茶の摘採が行われる14)のと比較すれば，五木地方の山茶利 用が，その純農業的焼畑によつて支えられていることが知られる.

山茶利用の様相はまた木場の種類にも関係がある. 一般に夏䇾木場にお いて茶の生葉の収量は比較的に多く，焼畑 5 年目に最大となる(第 3 表). そこでは茶期の早い期間に，葉の柔かい間に新芽だけが摘まれるので，生 葉の品質は優れている.除草などもある程度行われるので山茶の生育よく， 茶園的景観を展開する(写真 1).これに対して秋蝺木場では，茶は同じく $2 \sim 3$ 年目から摘まれるが，一般に葉が硬化し始める茶期の後期に摘まれ るので, 生葉の品質悪く，その摘及方は後にのべる丵林中の山茶の摘採に 近い乱獲15)であるため，茶樹の成育悪く，急速に収量が減少する(第 3 表)。

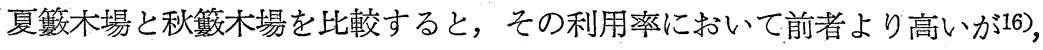
同一の関係が山茶利用にもみられる．秋簯木場のそれは掠奪的で，摘まれ た生葉の大部分が機械製茶工場に売られるのに対して，夏筊木場では，摘 まれた生葉は農家の手揉製造の原料となり，より集約的な利用が行われる のである．また，夏笅木場は集落に近い斜面の下部に位置し，秋簍木場は 集落から遠い山腹上部や山頂部に位置するのが普通であるから，山茶の利

13）焼畑は一般に純農業的齐畑と林業附随的焼畑に分けられ，前者から後者に進 化すると云われる.上野福男 (1938)：五家荘の焼畑耕作，地評，14,93～120頁. 沢村東平 (1946)：焼畑農業経営方式の研究（その 1 ), 開拓研究，2,35〜 52頁.

14）この地方では明治後期に植林が盛んとなつて，山茶利用がおとろえ，第 2 次 世界大戦後の森林乱伐の結果, 山茶利用が復活した. 篠田九万太(1954): 大分県 地誌， 142 頁。針葉樹の植林によつて山茶の成育が悪くなつたためである.五木 地方の焼畑は休閑期間中天然の雑木の繁茂にまかされることは，山茶利用にとつ て有利である.

15）新芽のみならず，古葉まで番茶原料として摘まれることもしばしばで，茎の みで葉のほとんどない山茎の焼畑に散在するのを見ることが稀でない.

16）上野，前揭. 
用は，焼畑の利用に並行して，谷底に立地する集落から遠ざかるに従つて， 粗放化してゆく.これは茶の生葉が摘採後，時間の経過とともに品質を低 下するため，遠くから運搬は不利となること，茶樹の生育が高度を増すに つれて衰え，集約的利用に不適となることなどのためと考えられる.

今日では，焼烟に生育する山茶は，ほとんどすべて利用され，自給用の 主食栽培を目的として行われる焼畑の最終的目標は，換金作物として山茶 の利用にあるといい得る状態であるが，昭和 10 年頃までは，山茶はその 生育の密な一部の焼畑に成育をゆるされるのみで，むしろ焼畑耕作の障碍 物として，根から刈り取られ，限られた範囲でしか利用されていなかつた。 利用の任方も粗放的で，その収量は少なく，反収にして今日の 3 分の 1 程 度であつた. 今日のように利用が高度化したのは, 後にのべるごとく, 特 に第 2 次大戦後の機械製茶工場の発達に負うところが大である. 機械製茶 の発展は，また，山茶の園茶化傾向を生み，集落に近接する部分の燒烟に 茶園を堌加せしめつつある.

五木村の耕地は $56.5 \%$ が焼畑である. 農家 1 戸平均 3.4 反の焼畑を耕 作する（第 4 表）が，この面積は実際はその 3 倍以上であり，専業および 第一種兼業農家は 1 町以上の焼畑を耕作すると推定されている. $3 \sim 5$ 年

第 4 表 五木村の経営規模別農家耕作状況 (昭27.5.1)

\begin{tabular}{|c|c|c|c|c|c|c|c|c|c|c|}
\hline \multirow[b]{2}{*}{ 経営面積 } & \multirow[b]{2}{*}{ 水田 = } & \multirow{2}{*}{\multicolumn{2}{|c|}{ 普通畑果樹園 }} & \multirow{2}{*}{\multicolumn{2}{|c|}{ 茶園＼cjkstart焼畑(1) }} & \multicolumn{4}{|c|}{ 経営耕地比率\% } & \multirow{2}{*}{$\begin{array}{l}\text { 総 農(3) } \\
\text { 家 数 }\end{array}$} \\
\hline & & & & & & 水田 & 尌園地 & 畑 & 焼畑 & \\
\hline 3 反未満 & 0.1 & $\begin{array}{l}\text { 区 } \\
0.6\end{array}$ & 区 & 0.1 & 1.2 & 2.2 & 4.1 & 32.0 & 61.7 & 122 \\
\hline $3 \sim 5$ & 0.3 & 1.1 & & 0.2 & 2.3 & 8.5 & 4.9 & 30.0 & 56.6 & 108 \\
\hline $5 \sim 10$ & 0.7 & 2.1 & 0.0 & 0.3 & 3.8 & 10.3 & 5.5 & 30.3 & 53.6 & 265 \\
\hline $1 \sim 1.5^{\text {町 }}$ & 0.9 & 2.6 & 0.2 & 0.6 & 7.1 & 8.4 & 8.2 & 22.5 & 60.5 & 42 \\
\hline $1.5 \sim 2.0$ & 1.8 & 3.7 & & 1.7 & 9.2 & 10.9 & 12.0 & 22.3 & 54.8 & 14 \\
\hline $2.0 \sim 3.0$ & 0.5 & 2.8 & & 0.3 & 19.3 & 2.3 & $2 \cdot 2$ & 12.2 & 83.3 & 3 \\
\hline 平 & 0.5 & 1.7 & 0.0 & 0.3 & 3.4 & & & & & \\
\hline (2) & $\begin{array}{c}\text { 丁反 } \\
30.1 .6\end{array}$ & $\begin{array}{r}\text { 丁反 } \\
93.6 .3\end{array}$ & $\begin{array}{c}\text { 丁反 } \\
1.0 .3\end{array}$ & $\begin{array}{c}\text { 丁反 } \\
15.5 .1\end{array}$ & $\begin{array}{c}\text { 丁反 } \\
187.7 .3\end{array}$ & 9.1 & 6.1 & 28.3 & 56.5 & (554) \\
\hline
\end{tabular}

（1）焼畑面積は 500 町を下らないと推定される.

(2) 林野率 $97 \%$ ，耕地率 $1.1 \%$ (田畑率 $0.6 \%$ ，焼畑率 $0.5 \%$ )

(3) 兼業農家率 $92.8 \%$ ，小作関係をもつ農家の割合 $49.8 \%$ 
[30. 4

間耕作し，10２0 年を周期とする焼畑耕によつて食料を自給するためには， 20〜30 町の林野を必要とするが, 林野所有が偏つているので17)，焼畑小作 が慣行している18)。焼畑小作慣行は山茶利用を規定する重要な条件の一つ であり，また焼畑小作は山茶の存在のために，複雑な形をとつている．焼 畑の小作料は現物納あるいは，夫役学衝によつて支払われるが，ここでは， 夫役学働の最大のものは山茶の摘採労働となつている19). 小作関係を山茶 の严属を中心に分類すると，(1)地主帰属，(2)耕作者帰属，(3)地主・耕作者 の共有折半の 3 類型となる. (1)の場合には小作料として課せられる手間に よつて茶が摘まれることが多く，(2)の場合には小作料はアワ・ヒエなどの 現物納（収穫の $1 / 4 \sim 1 / 2$ ), あるいは手間 (主に山茶の摘採と植林学働) によ つて課せられるが，小作料は徵集されず，山茶の利用は小作人にまかされ る場合も多いまた(3)の場合には，「摘み分け」ということが行われるが， 多くの場合小作人の手間によつて摘まれた茶が地主との間に折半されるの である.(2)と(3)が大半を占め，(1)は少ない．農家の $50 \%$ \%このような小 作関係を通して焼畑耕作を行い，自給生産と商品作物である山茶の利用を 可能とされる. 五木村で経営される茶園は一戸平均 0.3 反にすぎないが， これに対して山茶の生育する焼畑面積は 8.4 反弱と推定され20)，その茶生 産の大部分は焼畑に依存していることが知られる.

山茶の摘採は年 1 回，5月はじめから約 25 日間に行われ，手摘みであ る. 摘採の初期 10 日間は葉が柔く，手揉製造が可能であるが，以後は硬 葉化するので，摘まれた生葉は製茶工場に売られる. 農家 1 戸平均手揉製 造によつて 50〜70 貫，金額にして $4 \sim 5$ 万円, 生葉によつて 1 万円以上 ${ }^{21)}$

17）全農家の 7 割は林野所有 $0 \sim 10$ 町，4 割が $0 \sim 5$ 町の所有者. 無所有農家は全 体の 2 割を下らない. 村民有林野の $36.5 \%$ 共有林であるが，それは個人に分 割されて経営耕地に包含されているものが多い. 30 町以上の林野所有農家は 1 割 に満たない。

18）五木，五家䓅地方は旧藩時代，庄屋，地頭による土地支配が行われ，焼畑小 作が一般に行われたが，それは今日に及んでいる.

19）三浦保寿 (1953)：九州山地における焼畑経営隔絶山村の研究 (第一報), 人文 地理，4，491〜503頁.

20）茶園反収を生葉 100 貫，焼畑山茶のそれを 30 貫（実際は 20４0 貫）として， 昭和 29 年度の生葉生産量をもとにして推定した。

21）昭和 29 年度平均貫当り 40〜60 円であった。 
の収入をあげる。これは五木村全体についてみると換金作物収入の $81.2 \%$ にあたり，最大の収大源である22).

[B. 焼畑の休閑と山茶利用]焼畑は $4 \sim 5$ 年間の山茶摘採期間を含めて， 6〜 7 年間耕作され放车される. 再び焼畑化されるまでには 10～20 年の 休閑期間がある.山茶は烤畑の休閑期中は雑木林の下生えに混つて生存す るが，それもまた利用の対象となり，特異な茶業形態を出現させる．この 山茶は九州山地では，普通晚秋から春先き（11月下旬から 3 月）にかけて 摘まれる. 五木地方ではこの摘採期間は非常に長く， 6 月中旬から翌年 3 月におよふ.その摘み方は全くの掠奪で，新葉古葉にかかわりなく，枝ご と鎌で刚り取られ，あるいは，しごき摘まれて，ほとんど一葉も残さない 添どである.かような掠奪的な摘採は主として集落から遠くはなれた休閑 期の秋筫木場において行われ，夏笽木場には稀である.山茶の摘採はまた 烤畑化されない林野においても行われ，集落から $2 \sim 3$ 里以上も離れた他 村まで進出する，摘まれた茶の葉は製茶工場に売られ，番茶原料となる。 この場合には焼畑の山茶とは異なり，その所有が特に問題とされることは 少く，集落に近い部分を避ければ，完全に利用者の自由にまかされる23). このため休閑期の山茶は焼畑と茶園経営面積の少ない中小層農家にとつて 重要な利用対象であり，収入源となつている．五木村は年間 12１3 万貫 の番茶を休閉烧畑の山茶によつて生産している24). 農家はこの山茶の摘採 を製茶工場直属の生葉仲買人の要請によつて行うが，それは近年盛んにな りつつある河川工事，ダム建設，森林伐採その他の賃学働と競合関係にあ り，賃労㗢に比べて，山茶の摘採が有利なほど生葉が高価でないと，行わ れ得ない25).このため，山茶利用は景気に左右されやすく，年ごとの変動 が大である26).

22）他の換金作物の主なものは楮，こんにやく，椎茸，大豆である.

23）このことは九州山地全域に共通であるようである. 同種の利用形態は静岡県 富士郡大淵村でもみとめられた。

24）これは全茶生産の $24 \% に$ 相当する.

25）昭和 29 年度兵労働は平均 250 円. 山茶は平均 1 日に 7 ～貫採集が可能であ るから，生葉価格 35 円(貫当り)ぐらいまでは，山茶摘採を有利とした.

26）五木地方同㥞山茶利用のさかんな米良地方の場合を前者の資料不足を補うも のとして代用すると，昭和 28 年度西米良村では 12,290 貫， 29 年 29,020 貫. 東 米良村では各々 2,500 貫，9,080 貫で，非常な変動をみせている.（宮崎県特産課 
[C．機械製茶工場の山茶依存]山茶地域には今日なお，近世以来ひき つがれてきた手搡釜炒製茶が普及しており，自園自製形態が存続している. この製茶法は生葉を炒るための平釜を唯一の製茶用具とするごく簡便な製 法で，他地域から高い運賃を費して製茶資材を購入する必要がないが，こ の点が，交通不便な山地に旧式な製茶法が存続する理由であると思われる。 大正初期以来全国的に茶業地域を警つた製茶機械化の波は九州山地にも及 び，五木村には大正 2 年に製茶機械が導入され27)，現在 (昭和 30 年) 13 戸 の機械製茶工場をもつまでに発展した。製茶工場の業態はいつれれ買葉製 造で，生葉を購大して，主に釜炒茶を製造する28)。第 2 次世界大戦前は， 製茶工場の活動期間は茶期の約 15 日間にすぎなかつたが，戦後は番茶の 製造を開始して，活動期間は著しく延び，4月をのぞく他のすべての月に， 間歇的ではあるが，製茶がなされている。延日数 120 日以上活動する工場

第 5 表 五木村における機械製茶工場所有者の耕地および山林所有

(昭 27.5.1)

\begin{tabular}{|c|c|c|c|c|c|c|c|c|c|c|c|}
\hline & 茶園 & 水田 & $\begin{array}{l}\text { その他 } \\
\text { 樹園地 }\end{array}$ & 普通畑 & 焼畑 & $\begin{array}{l}\text { 耕地 } \\
\text { 合計 }\end{array}$ & 用材林 & 雑木林 & 竹林 & 合計 & 備考 \\
\hline 板 木A & 区 & $\begin{array}{r}\text { 区 } \\
7.5\end{array}$ & 区 & $\begin{array}{l}\text { 反 } \\
0.6\end{array}$ & $\begin{array}{l}\text { 区 } \\
3.7\end{array}$ & $\begin{array}{r}\text { 区 } \\
11.8\end{array}$ & 町 反 & $\begin{array}{c}\text { 丁反 } \\
4.7 .0\end{array}$ & 町 区 & $\begin{array}{c}\text { 町 区 } \\
4.7 .0\end{array}$ & $\mid$ \\
\hline 小 鶴 B & & 2.0 & 0.4 & 5.6 & 10.0 & 18.0 & 14.5 .0 & 703.5 .0 & 3.0 .0 & 722.8 .5 & 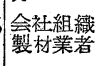 \\
\hline 宮 園C & & 2.5 & & 0.5 & 10.0 & 13.0 & 10.0 .0 & 15.3 .0 & & 55.3 .0 & 同上 \\
\hline 上平瀬 $\mathrm{D}$ & 3.2 & 2.5 & & 0.3 & 10.0 . & 16.0 & 10.0 .0 & 5.2 .5 & & 65.0 .0 & \\
\hline
\end{tabular}

もある. 前述の焼畑休閑地や林野の山茶利用は戦後のこの番茶製造の要求 に応じて発生したものである.製茶工場29)はいつれも山林の大規模所有者 である。彼等のうち 3 戸は製材業を兼ねてをり，しかも，いずれも経営面 積 1 町以上の耕作者でもあり，比較的広い茶園を経営する上尿農家である (第 5 表).

\section{の資料による)}

27）大正末年に機械製茶工場 7 戸で動力は水車を使用していた.

28）他に蒸製煎茶と少量の紅茶がある・紅茶は日東紅茶 K.K.の委託生産で数年 前から始まつた。

29） 13 戸中 3 戸は会社組織で，1戸は明治末期に静岡県から招聘されてきた茶業 技師の出身である. 彼等は五木村の全生産の 5 割以上を生産するが，その生産額 つ 4 割以上は番茶である. 
一般に茶は現金取引を慣翼とするが，戦後，機㳦製茶工場は原料生葉の 購入資金を静岡市の茶商に仰ぎ，また製茶機械設置資本をも導入した。そ して茶の大部分を静岡市の茶市場に直送することになつた。従来，その製 造する茶が釜炒茶であるため，市場を九州と冲繩に限られていたこの地方 の茶が全国的な市場組織に組入れられることになつたのは，わが国の茶業 が，第2 次世界大戦の影響を蒙り，茶園は戦前の3 分の 2 , 生産量は 3 分 の1に減じ，国内需要をも充たし得ないまでに荒廃した，戦後このような 時期で）（昭和 $23 \sim 24$ 年以後）ある. 近世前期（17世紀後半）以来集荷市 場として，この地方の茶を支配してきた人吉や，下益城郡小川町などの茶 問屋の支配を，農家において製造される手揉製茶のみに限定し，そして， 製茶工場を通じて，五木地方の山茶を静岡河に直結し，その需姿に応じて 茶を鋚造せしめられることになつた楔機は，この静岡市の茶商資本の導入 と，それによる戦後の顕著な機械製茶の発展である。それはまたすでに述 ベたような山茶の利用領域の拡張, 充実, 焼畑における山茶利用の普遍化 と集約化，および焼畑休閑地と林野への山茶利用の拡張の楔機でもあつた のである。

製茶工場はすでに述べたように農家から生葉を購入するのであるが，農 家は手揉製造が不可能になつた茶期の後期に生葉を売るにすぎないので， 機械製茶工場の買葉製造の基礎は貧弱ならざるをえない。製茶工場はこの 不利を補うために，焼畑休閑地の 山茶に依存して, 番茶の製造を行 いそれによつて工場の維持をも はかるのであるが，この番茶原料 生葉の摘採はまた貨学働との競合 関係に左右されるため，番茶依存 の経営は安定したものではないの である。この不安定の対策として， 製茶工場は集約化された茶園の経 営を要求し始めた。彼等は山茶を 園茶化することによつて，茶園を 開設しようとしてをりすでに7

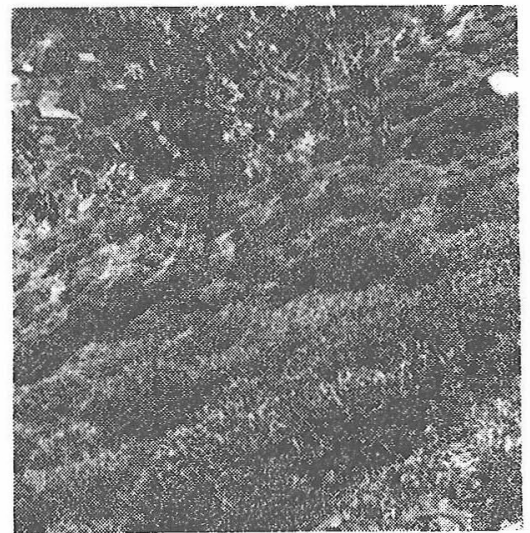

写真 2 園茶化された山茶 （瑨畑 7 年目） 
反以上の園茶化をなし遂げたものもある(写真 2 )、今日ではまだ園茶の山 茶に対する比重は極めて低いが，これは山茶利用が機械製茶の導入を楔機 として, 高度に発達し, 天然の山茶依存の段階から茶園段階へ移行しはじ めた兆候と見做すことが出来るであろう.

〔D. 山茶利用の特殊性】わが国の現代の茶業は，自園自製，生葉売，買 葉製造の 3 種の茶業者の結合によつて組織されるが，これら茶業者の分 化30)は，茶園でなくて，山茶に依存する五木地方の場合には，特異な形を とつて現われる。手揉製茶が可能な期間は自園自製であり，不可能になる と生葉売化し，茶期の前半と後半に，これらの両形態が同一茶業者におい て出現するのである．また茶園の場合と違つて，山茶はその生育場所の相 違によつて利用方式が異なり，それが茶業者の業態の変化と関連している 点が特徴的である，概括的に，次のようにいうことが出来るであろう．夏 籍木場の山茶は茶園とともに自園自製と結合し，山茶の多くは農家によつ て上質の茶に製造される。 また秋簍木場の茶は休閑焼畑のそれと同様，生 葉売の対象となり，買葉製造家によつて中下級の番茶に製造される．農家 は大約半分ずつの割合で，これら両木場を耕作するから，したがつて，そ の茶業形態を二様に変化することになるが，これは茶園による茶業のみに みられない，山茶利用茶業の顕著な特色であるといわねばならない.

山茶利用の存立条件 山茶の利用は主として, 食糧生産を目的とする焼 畑耕作に附随して行われる。したがつて，焼畑の存続条件を考へることは， 山茶利用のそれを考察するゆえんである．五木地方の焼畑は純農業的焼畑 が大部分であり，林業附随的焼畑は少ないが，前者は燒畑の植林化につれ て次第に後者に移行して行くと考えられる，したがつて，焼畑に植林化が 進展しない理由を考えることは，五木地方に純農業的焼畑の存続する理由， さらに特有な山茶利用の存続条件を考察する糹口となるであろう.

交通条件は焼畑の植林化に関係していると思われる. 五木・五家荘地方 は地勢的交通的に隔絶的環境にあり，経済活動の条件にめぐまれていない， 最近まで，この地方の大部分を占める林野（五木村総面積の97\%）の利用

30）茶業者の分化は第 1 次世界大戦前後から進展した製茶の機械によつて惹き起 されたものである.これら茶業者の類型には，中間型があるが，便宜上ふれない ことにした。 
はほとんど焼畑のみで，木材の利用は限られていた。現在でも五木村の植 林面積は林野の $9.7 \%$ に過ぎず， $98.1 \%$ \%然の雑木林である.植林の歴 史は古いが，植林の大部分は最近 20 数年来のものであり，特に戦後に増 加をみた31)。木材に経済的価值が認められ，一般に利用されはじめたのは， トラックがこの地方に入つた昭和初期以降である。上野氏によれば昭和 10 年頃, 五家荘地方ではまだ木材はほとんど無価值であつた32).木場切りの際 に伐採される雑木には，樫・樽・椎など薪炭材として有用な樹種が含まれ ているが，これらが薪炭材として利用されはじめたのは第 2 次大戦中であ り，いまたにに，全く利用することなく焼却し，焼畑の肥料としてしまうも のも多い33).この地方の林業と製炭業は明治初年以来，他県人（土佐，紀 州）によつてある程度行われ，次第に盛んになつてきたが，農民が極積的 にそれに参加するまでに至つていない状態である，普通行われる針葉樹の 樹林は，植苗から伐採までに $30 \sim 40$ 年を要し，植苗後 $3 \sim 5$ 年の耕作を 可能にするが，雑木林の焼畑に比べると 2 ～倍の焼畑休閑期間を生ずる ことになるししたがつて林業附随的焼畑で食糧を自給するためには，純農 業的焼畑よりも広大な焼畑用地が必要であり，焼畑の植林化には食糧生産 の機会を失う危険がともなわれる，それゆえ，燒畑植林化のためには，食 糧生産を焼畑に依存しなくなることが必要である，それには焼畑の常畑化 による集約的生産によつて食糧を自給するか，商品作物の栽培や，林業労 働・木材加工・製孷その他賃学働などの兼業によつて食糧購入資金を獲得 することが必要と考えられる.しかしながら，現在までのところ五木地方 には山村に兼業の機会をあたえる山村的木材加工，その他の林野資源の加 工は存在せず34)，またこの地方の最大の兼業機会である林業労㗢も家計補 助的なものでしかない35)。また急傾斜地利用の焼畑の常畑化には限界があ

31）植林面積，昭和 22 年 9 町，25 年 156.9 町， 27 年 250.0 町，28 年 320.0 町と なつている.

32）上野，前揭.

33）上野氏は焼畑に雑木の樹幹が燒けのこされたままになつている景観を記載し ているが，今日では雑木が利用されることが多いため，かような景観は多く目に しない.

34）たとえば家具，下駄などの製造，あけび細工，竹篭造りなど.

35）五木村の農家は $92.8 \%$ 兼業農家であり，その大部分は林業関你の兼業であ る. 第 1 種兼業が $80 \%$ 占めている. 前揭(3)「村のすがた」33頁 
る.これに反し山茶は商品作物として，極めて手近なものなのである.山 茶を茶園化して集約化に経営することは可能であり，すでにある程度行わ れている.しかし，まだ五木地方では茶園の管理は，除草と刈敷を施すの みで，ほとんど施肥しないため，年に 1 回の茶葉の摘採を可能にするにす ぎない現状である.わが国では，今日，年に 1 回の茶葉の摘採によつて茶 業地域として成立しているのは，玉露・碾茶が製造された場合に限られて おり36)，玉露や碾茶の製造は資本と特殊技術を必要とするから，山茶の茶 園化によるかやうな商品生産としての茶業の成立は困難であるように思わ れる. 勿論多量の肥料の投入は，年 $3 \sim 4$ 回の摘採を可能にするのではあ るが，五木地方にはかような茶園集約化を有利にする条件の存在は疑問で ある.かように考へてくると，五木地方では植林を直接，間接促進せしめ る基礎条件が成立しているとは考えられない，現状では焼畑で，食糧生産 を行いつつ，山茶をある程度管理して，商品生産を同時に行い，木材利用 をも包含するという形態で存続することが植林を進めるよりも有利である と思われるのである.

植林を制約するものにはまた，社会的条件として，燒畑小作が考えられ ねばならない，五木・五家荘地方では，地主は焼畑小作が慣行するだめに， 焼畑適地には植林することが出来ない37)。勿論，植林化することなく焼畑 小作を維持することには地主にとつて有利な点が多いと思われる．焼畑の 小作料は夫役制による場合が多いが，夫役によつて地主は焼畑と常畑の耕 作を可能とされ，自給食糧と茶という商品作物の収穫を確保出来る.物納 に較へてて，課税対象とならない夫役は，より大きな収益を地主に確保せし める38)。これに反して，植林化は焼畑小作の解消を条件とするが，それは 小作農民から食糧生産の機会を失わしめるのみならず，地主の焼畑経営に 必要な労働力と，ほとんど唯一の商品作物である山茶の利用をも不可能に する＼cjkstart植林化にはまた，森林に対する課税が焼畑に対するそれより高率で あることや，山林の解放に対する危惧の念などの障碍があり，それらが地 主をして焼畑の存続を有利とし植林を躊躇せしめる条件となつていると思

36) W. H. Leonard \& R. Roberts (1949) : Tea in Japan, p. 28.

37）前揭(3) 51頁.

38）三浦，前揭. 
われる。他方，焼畑小作はすでに述べたように地頭，庄屋支配の名残りで， 地主と小作の間にはまだ主従的関係が残存しているが，これはまた地主を して焼畑小作を解消し，焼畑をより高度な林業的土地利用に改変して，永 年の慣習を破ることを恩情主義的に思いとどまらしめる働きをしていると 考えられる。

かくして，烧畑は現在さきにのべた多面的利用による経済的相対的有利 性と，山村における特殊な社会的条件によつて支えられ存続していると考 えることが出来るであろう，燒畑の有利性に関しては山茶という天然資源 の存在と，全国的な茶市場との結合による山茶利用の高度化が重要な条件 となつているのである.

むすび 以上わが国における茶業の原始的形態を保存すると考えられ る五木地方の山茶の利用形態と，その存立条件を考察したが，山茶利用は 焼畑耕作に基礎をおくものであり，焼畑の盛衰と，茶に対する需要によつ て変遷することが知られた。燒畑の消滅は山茶利用を消滅せしめるが，焼 畑を消滅せしめる最大の楔機は燒畑の植林化である，他方，茶に対する需 要増加は，すでに見たように，山茶の園茶への進化を䓯き起し，粗放的な 山茶利用を解消させ，集約的な茶園形態に移行させる楔機となると考えら れる.たとえばこのような例を福岡県八女郡星野村に見ることが出来る. そこでは，明治中期に宇治から玉露生産の技術が導大されてこの進化がな しとげられている．すなわち，山茶利用は，一方では焼畑という原始的農業 と消滅の運命をともにするであろうが，他方では，茶に対する強い需要と， それに応じ得る技術が得られれば，園茶形態に進化しうるのである．この ように考えれば，わが国の茶業が山茶利用から発達したと想定すれば，近 畿から東海，関東にわたつて各地に中世にすでに成立した茶業地域には， 当時すでに，園茶化を若起すに足る需要と技術が存在していたものと推定 され，そして，九州，四国などの山地には，市場から隔絶せられていたた めに，近年ようやく園茶化の波が到達したと考えることも可能ではないか と思う。また，山茶利用の消滅した地域には，上にのべた需要と，技術の 不足を推定できるであろう.

この研究には, 東京教育大学の尾留川博士，有末・正井両氏，農業技術研究所上 野博士，農林省特産課名倉万雄氏，同統計調查部の鈴木隆治氏，五木村収入役佐藤 光昭氏その他多数の方々に指導と調查の便宜を仰いだので，ここに記して感謝の意 を表するものである. 